\title{
Development of Social Security in the Czech Republic in the Context of Current International
} Treaties

\author{
Paed Dr. Zuzana Horváthová, Ph.D. \\ Department of Law and Public Administration, Metropolitan University Prague \\ zuzana.horvathova@mup.cz
}

Assoc. Prof. Ing. Josef Abrhám, Ph.D.

Department of Law and Public Administration, Metropolitan University Prague

josef.abrham@mup.cz

Assoc. Prof. JUDr. Iva Chvátalová, CSc.

Department of Law and Public Administration, Metropolitan University Prague

iva.chvatalova@mup.cz

\begin{abstract}
The aim of the paper is to evaluate the state-of-play of social security with a focus on pension insurance in the Czech Republic and this due to the potential use of international agreements with individual countries of the European region. The contracts are divided in terms of whether the state is a part of the European Union, or remains outside that integration. The use of international agreements in the field of social security currently appears to be important for a number of reasons such as tourism, openness of the labour market, economic dependence on international trade and various kinds of migration. The issue is covered by interdisciplinary studies, where the knowledge of the humanities and economic fields mingles. Overall, the work provides a comprehensive overview of international agreements in the territory of the Czech Republic, not only in the period of the capitalism, but also captures the recent history, the period from the 1960s up to now, when the Czech Republic used to be a part of the socialist bloc, At that time most important become agreements and contracts with the former USSR.
\end{abstract}

Keywords: international agreements on social security, documents, papers, pension insurance, economic and social area of a state, benefits/allowances in the international insurance

\section{Introduction}

Given the fact that the Czech Republic used to be for many years part of other government departments and different political establishments, its social system was affected by that situation. The development of social insurance in our country since the beginning of the last century up to the present is the one of the goals of this article, another partial goal is the establishment of international agreements on social security that affect the Czech Republic.

Today, almost all countries of the European region modernize and reform their social security system, while the largest reform recently took place mainly in the field of pension and retirement systems. The reason for that is the increase in average life expectancy and the growth of the post-productive age group of the population at the expense of people of the working age. Any reform is a process of long-term nature, where the depth of changes varies from country to country and is influenced by social values and system costs. Individual differences result from historical development and the embedment of the individual systems.

Davidová (2013) works with the fact that „Pension schemes are influenced by historical traditions and social factors of the countries concerned, which translates into a great variety of different systems. The most advanced countries then undertake changes of their pension systems very carefully and rather significant changes appear in the new EU countries."

The overall system of social security is defined in developmental studies and treaties such as the Paris and the Rome Treaty. Among basic pillars of social policy also belongs the Treaty of Nice, which made the Union capable of helping new 
candidate countries effectively. The level of development as well as the social situation in the European Union is constantly building up and the EU is trying to adapt flexibly to current problems.

\section{Social security law in the Czech Republic}

Since May 1, 2004 the Czech Republic has been a Member State of the European Union and one of the fundamental principles of the EU social system is a free movement of people which means a right of each EU citizen to move freely. For this reason, the migration in some way increased together with the obligation of Member States to treat migrant citizens of the European Union so as not to limit their ability to work within this area.

A basic purpose of this regulation is to ensure that the migrant employed in multiple states does not lose his entitlement to social benefits because of another citizenship or a permanent residence.

Regulations of the European Community are restricted to the coordination of existing national social systems, without interfering in their deeper nature. Similar procedures and regulations were in the form of multilateral international conventions adopted also within other organizations such as the Council of Europe or in the International Labour Organisation. Provided, that sometimes the provisions are based only on some fundamental coordination principles which are very similar in terms of the content. The regulations of the European Union are characterized by their direct applicability and a priority application compared to other regulations across the entire EU.

The provisions of the European Communities on social security concern all the Member States and at the same time they are binding for each state on its national level. They cover:

- pre-retirement benefits,

- benefits subject to accidents at work and occupational diseases,

- family benefits,

- $\quad$ sickness benefits,

- $\quad$ benefits subject to disability,

- maternity and equivalent paternity benefits,

- inheritance benefits,

- age benefits,

- funeral allowances,

- unemployment benefits.

According to the Department of the European Union and International Cooperation MLSA (2009) it pays that despite some successes in unifying the conditions contained in the various national social security systems their full harmonization has been and still is a question of a distant future. However, their mutual interconnection, and in this case we are talking about coordination, has become a reality, the origins of which date back many decades ago. The initial coordination between the two states on the basis of individual bilateral agreements was soon added and promoted by multilateral coordination among several countries which reached its summit on the European continent within the Framework of the European Union.

Shall a coordination mechanism apply in a given country of the European Union; the regulation represents a crucial issue for decision making. For this reason, the protection stemming from regulations apply to:

- $\quad$ stateless persons and refugees, if they live in EU Member State,

- citizens of a Member State of the European Union (i.e. The EEA and Switzerland),

- family members and surviving dependant of the above persons regardless of their nationality. 


\section{Development of social security system in the Czech Republic}

The economic situation of the given period always had a major influence on the development of the social sector. The first transformation of the state occurred in the 19th century when a care for slum community was transferred to municipalities.

At the beginning of the 20th century, a so called pension's standard improvement for civil servants is introduced. Factory owners had only one goal and that was making employees dependent on the company and driving a wedge between officials and workers.

In the period after the first World War, with newly independent Czechoslovakia, social problems of that time were getting sharper. Many families lost their men as breadwinners, bad hygiene conditions lead to the spread of disease and depending huge unemployment and food shortages. Social policy sought to address that situation by a means of cash benefits for widows, orphans, by adapting working conditions and care for the unemployed. However, due to the economic crisis at the turn of the 1920s and 1930s, the payment of benefits got complicated.

In 1925 Gallas defined the social insurance system as a set of public facilities built on the principle of equivalence (balance) between revenues and expenditures, providing a legal entitlement to certain, mainly cash benefits and preventing an economic catastrophe.

In 1945, the Central Council of Trade Unions established a national pension and health insurance. This law, however, due to the post-war situation in the Czech Republic, came into force and began to implement only in 1948.

Due to the establishment of a new political system, in 1951 there was taken over a Soviet model, under which the Central National Insurance Company was cancelled, and the state took a care for payments. Its funding was realized from taxes. In this period, the most important law was the act on pension insurance of miners.

According to Vrba (1948), the oldest branch of the social insurance is mining insurance policy. Tough and dangerous work of miners demanded special protection against illness, disability, injury and death. Already in the early medieval mining orders we can find notes about brotherhood and fraternal offices.

In the totalitarian regime, the social system followed to a large extent the social system of the former USSR. In 1957 there was a reform of the system of national insurance. This law was based on the fact that the amount of benefit was derived from salary, length of service and a final factor to calculate the amount of benefits represented also the differentiation by occupational category. The law was modernized in the early 1970 s, where the original regulation was complemented by support for families with dependent children.

The change of both the economic system and political ideology after 1989 led to a necessary transformation in the social system. From the ideological point of view during the time before 1989 social problems did not exist. After the onset of the capitalist economic system, great changes occurred in society, social certainties, demography as well as the economy.

In 1993 began the process of separating the financing of social insurance policy from the state budget via paying the insurance outside the tax system. However, insurance still remained the revenue of the state budget, which resulted in depletion of reserves for completely different purposes than for which they had been originally created. A separate account emerged only in 1996; however there was no excess on the insurance revenues any more.

Brejcha and Vořišek (1996) stated that by a security principle in retirement security is meant the application of such legal principles defining the scope of the security policy (of the system of benefits), when the substantive conditions of benefit claims and the method of financing, in which the definition of basic legal institutions depend on the mandatory criteria enshrined in law regulation.

In 2008 occurred the main innovation of the Pension Insurance Act of 1995, and this law came into effect in 2010. The amendment to the Act brought about a gradual increase in the retirement age to 65 years, an extension of the insurance period required for the entitlement to retirement pension from 25 to 35 years, the introduction of three-tiered disability and in terms of education there emerged a change when the duration of study obtained after December 31, 2009 will not count as an income replacement insurance period. There was also an increase in penalties for early retirement and the increase in the age limit for permanent entitlement to widow's or widower's pension.

Currently in the Czech Republic there is a share of 1.8 contributors to social insurance per one pensioner, and unless there will be any demographic and social changes by 2050 the number of contributors per pensioner will go down to the level of 1.2. Hence it follows that future generations will face lowering of the replacement rate or providing pension payments at a 
later age or a growth of the taxation of economically active generations. Owing to a huge redistribution between generations and people with different income levels, there is only a weak link between the amount of contributions paid and the amount of pension paid. The current pension system is financed from the current yield premiums that people pay from their wages and entrepreneurs from their profits.

The pension system in the current legal regulation of the Czech Republic is financed from the current yield premiums. This notice applies to employees through their wages and entrepreneurs through their profit. Due to changes in the age structure of the population (the increase in the post-productive population at the expense of the productive one), there is only a weak link between the amount of the contributions paid and the amount of the pension paid.

One of the most important parts of social security in the current social policy is the pension scheme. In the Czech Republic it is divided into three basic parts:

- mandatory pension insurance,

- pension scheme with state contribution,

- retirement saving.

Mandatory pension insurance covers all economically active persons. These are so called state pensions and are defined in terms of the benefit and continuously funded. Since January 1, 2013 it is represented by the first pillar of the pension insurance. Against the previous period, there were several changes and the most important is that due to the gradually increasing life expectancy there will continue the increase in the retirement age of men at the current pace which is by about 2 months per year, even after the age of 65 . The second factor is that it will accelerate the pace of increase in the retirement age for women with the year of birth in 1956 and later by six months (from the current four months) a year. The complete unification of the retirement age for men and women will take place in the year 2041.

A supplementary pension scheme with state contribution is funded through the contributions from the participants of this scheme and though creating savings via pension funds by December 31, 2012. Since January 1, 2013 it creates the third pillar of the pension insurance and is called an additional pension saving scheme. Via the transformation of this scheme emerged the so called participating funds.

Compared to the previous period, significant changes occurred, specifically that the condition of participation is bounded by at least 18 years of age, new participating funds will differ from pension scheme funds in a way that their participants will not be eligible for an early retirement pension and the law will not guarantee a non-negative evaluation. Money in the pension funds is not insured and in case of death it becomes part of the heritage. There also emerge the so called prepensions which qualify for saving the people who are in a period of up to five years before retirement age, the entitlement is drawn from funds in the account in the system of supplementary pension savings and one needs to have at disposal such a sum, which will allow to pay a monthly benefit of at least $30 \%$ of the average wage and the minimum saving period is five years.

The retirement saving is the last part of the pension scheme, which was established on January 1, 2013 as the second pillar. The entry into this pillar is voluntary, any natural person aged from 18 to 35 years may join and the participation in the second pillar does not affect the amount of the widow's or widower's pension. In case of death of the participant in the pay-out phase the balance on the retirement saving becomes the subject to inheritance (this is valid for the choice of the old pension for twenty years or orphan's pension for five years). In case of a lifetime pension payment the money is not a subject to inheritance.

Currently, there is a discussion about the abolition of the second pillar either on January 1, 2016 or 2017 on the ground that it is not suitable for most people and creates financial benefits only for wealthier residents of the Czech Republic.

According to Hamalčíková (2014) about 83000 people that have since January 1, 2013 entered the second pillar will have to decide what to do with the money from the cancelled part. They can have the money sent on their accounts or may have inserted it into the first pillar or the third pillar. They will have to notify the pension companies until September 2016 about their decision of how to treat the money loaded in the second pillar.

The other basic benefits provided by the state social insurance system are: 
- a child benefit: this benefit is eligible for dependent child if the decisive family income does not exceed the amount of the determined subsistence income of the family and the contribution is divided depending on the age of a dependent child and a specified period,

- a social allowance: the purpose of this benefit is to help low-income families to cover the costs of covering their needs. The amount of the benefit is variable, with higher family income the supplement decreases. The entitlement for this supplement is bound to a dependent child and the family income limit,

- a housing allowance: the aim of this benefit is to contribute to the cost of housing to families and individuals with low incomes,

- a foster care benefit: the state contributes to the needs associated with caring for a child placed in a foster care. Among the benefits of a foster care is for example foster parent remuneration; a contribution when receiving a child or a contribution to the child's needs,

- a funeral allowance: this benefit is entitled to a person who arranged for the funeral of a dependent child, or the person who was the parent of a dependent child under the condition that the deceased person had on the date of death of a permanent residence in the Czech Republic.

\section{International agreements on social insurance in the European area}

The basic sense of international agreements is to ensure the rights of people who migrate between two or more contracting States. In the current social security system there are commonly used means of the coordination in the field of social security.

International treaties or agreements can be divided into three categories according to their nature:

- proportional agreements,

- territorial agreements,

- combined agreements.

The rules for determining the competence of the social security legislation serve to ensure the application of the principle of legal regulations of one country. The application of the relevant provisions of international agreements on social security cannot be used in a situation when a person covered by the agreements is insured in both States or vice versa in none of them.

A lex loci laboris principle - is the basic rule for determining the jurisdiction for social security legislation. A person who is employed or self-employed person is a subject to the legislation of the Contracting State in whose territory is gainfully employed, regardless of place of residence (rule of lex loci laboris).

Proportional agreements are based on the principle of equal treatment, a single insurance, an aggregation of the covered periods and the payment of benefits in the other Contracting State. The principle of equal treatment anchored in the agreements stipulates that via the application of the legislation of one Contracting State the citizens of the second Contracting State, to which the relevant agreement refers, are equal in terms of rights to the citizens of the first Contracting State; this equality applies not only for rights but also for obligations.

For assessing the entitlement to pension benefits it pays that each of the Contracting State grants and pays a pension equivalent only to the insurance period itself.

These agreements were concluded by the Czech Republic (Czechoslovakia) with Australia, Bulgaria, France, Chile, Croatia, India, Israel, Japan, the former Yugoslavia (in relation to Macedonia, Slovenia, Bosnia and Herzegovina, Serbia and Montenegro), Canada, Korea, Cyprus , Lithuania, Luxembourg, Hungary, Moldova, Poland, Germany, the Quebec, Austria, Romania, Russia, Spain, Switzerland, Turkey and USA.

Territorial agreements are based on the principle of the residence of the insured person (lex loci domicilii principle). It means that the benefit is conferred by the State in which the applicant is on the day of the claim for residency. For instance in case of pensions, the state pays a pension even for a period of the employment (insurance) obtained in the other Contracting State. If there is a change of the residence of the pensioner to the other Contracting State, this State takes over the obligations of the first Contracting State 
On a territorial principle only the agreement with the former USSR was established. In terms of the history as well as the substance, this agreement is already outdated and inadequate to common standards on social security coordination. As for the validity, the agreement was in relation to the Russian Federation terminated on December 31, 2008 and in relation to the other successor states of the former Soviet Union (Armenia, Azerbaijan, Belarus, Georgia, Moldova, Kazakhstan, Kyrgyzstan, Tajikistan, Turkmenistan, and Uzbekistan) on September 22, 2009. Regarding the Ukraine and Moldova there were negotiated new agreements, which entered into force on April 1, 2003 (Ukraine) and on October 1, 2012 (Moldova). On December 8, 2012 a new, modern type of proportional treaty was signed with the Russian Federation, which entered into force October 1, 2014.

Combined agreements represent the ones concluded with Slovakia and the Ukraine. The territorial element is contained in the provisions relating to the assessment of the insurance periods acquired by a certain date (in the case of the CzechSlovak agreement upon a termination of the Czechoslovak federation; as for the agreement with the Ukraine on the date of the entry of the agreement into force). These periods of insurance are assessed only by one Contracting State, irrespective of in which Contracting State the periods were completed. As for the terms of the insurance periods after that date, these are already assessed under the principle of proportionality that is by the State on the territory of which they were actually recovered.

Not all bilateral agreements relate to the whole area of social security. Such specific agreements are:

- Intergovernmental Agreement on the Settlement of Pension Claims between Czechoslovakia and Greece of 1985; this agreement addresses pension entitlements of the so-called Greek re-emigrants,

- Agreement with the Netherlands of 2001, which governs only the export of social insurance benefits,

- Governmental agreement between Czechoslovakia and the USA of 1968, which only provides for mutual payment of pensions between the Czech Republic and the USA.

\section{Conclusions}

The economic, political, and social situation of the given state affected the type, amount and conditions of the eligibility for retirement benefits in the periods examined by the authors. The situation also had an impact on the extent of the benefits provided. Initially workers were compulsorily insured only for sickness benefits and for the events of an accident, then gradually the insurance for the events of sickness, disability and old age were added and finally inheritance pensions have been derived.

We can say that the conditions for the entitlement to a pension have been from their inception until today basically the same, but they are mainly influenced by economic, political and social problems of the state. Each era brought along its own specific problems, which had to be dealt by the state. Also due to the increase in the economic system of the country, we can say that social insurance is so complex that it will never be possible for anyone to establish such conditions that cover all the needs of the country's population to general satisfaction. Although there are a large number of publications, studies and articles dealing with issues of social security, it cannot be said that a universal key has been found solving problems, which are based on the current social situation in the state and the region.

Today we can confirm the fear that the introduction of pension saving in the second pillar does not, in view of the current government, contribute to the effect expected. On the contrary, it is noted that this pillar is inefficient, inconvenient for most people and generates profits only for wealthier citizens. The estimated date of the scheme withdrawal is January 1, 2016 or a year later. The issues of the current retirement saving plans and supplementary pension schemes are in the hands of the Ministry of Finance.

The basic compulsory pension insurance is defined in terms of benefits and is continuously funded. It is a universal one and covers all persons in the economically productive age. The law regulation is uniform for all the insured, there are no special sectorial or occupational schemes. Only from organizational and administrative point of view there are certain derogations for people in special professional groups such as the so called hard power departments (e.g. soldiers, firemen, policemen, customs officers).

Less than one percent of the population gets the old pension, which is deducted from the basic pension scheme. 
In case of moving a pensioner when he obtains a new residence, the state has to grant the pension in the amount according to its regulations. At the same time the state of the original residence terminates the payment of the pension. The pension shall be granted under an international agreement for the duration of the employment completed in the original state without compensation from this country, despite the fact that a citizen did not contribute at all to the welfare system of a new residence.

Thus it can be stated that the setting of a fair pension scheme is an issue in many European countries. The efforts to eliminate the negative impact of migration of population from one country to another in the area of social security represent the coordination regulations that affect various international agreements in the sense that they are directly binding and are supranational legislation based Community law and coordinate social security schemes in all Member States.

In conclusion we can say that when determining the eligibility for pension benefits individual states decide, on the basis of bilateral agreements, in a similar way.

\section{References}

[1] Čajka, P. Current Demographic Problems. in: Research of Non-Military Aspects of Security. Faculty of Political Sciences and Interantional Relations, Matej Bel University, Banská Bystrica, 2011, P. 34-67, Isbn 978-80557-0290-2

[2] Gallas, J. Výklad K Zákonu O Pojištění Zaměstnanců Pro Př́pad Nemoci, Invalidity a Stáři. Praha: Lidové Knihtiskárny a. Němec a Spol., 1925. S. 15.

[3] Citterbart, K., Schrutz, J., Vrba, V. Hornické Pensijní Pojištění. Praha: Orbis, 1948.

[4] Kocourek, a., Laboutková, Š., Bednářová, P. Vazby Lidského Rozvoje Na Ekonomickou, Sociální a Politickou Dimenzi Globalizace. E+M Ekonomie a Management. 1. Vyd. Liberec: Technická Univerzita V Liberci, 2013, Roč. 16, C. 2. S. $10-21$. Issn 1212-3609.

[5] Rimševičs, I. Lessons from Latvias Internal Adjustment'S. Bank of Latvia. 2012.

[6] Ušiak, J. 2013. Security and Strategic Culture of the Visegrad Group Countries. Banská Bystrica: Matej Bel University, 2013. 200 S. Isbn 978-80-557-0515-6

[7] Hamalčíková, K. Druhý Piliřr Důchodového Pojištění Bude Zrušen: Druhý Dủchodový Piliřr Skončí. Jak Mǔžete Naložit S Penězi? Online 6. 8. 2014 Cit. 2015-04-1. Dostupné Z: Http://Www.Usetreno.Cz/Druhy-Pilir-DuchodovehoPojisteni-Zrusen/

[8] Bureš, J. Ekonomické Souvislosti Dosavadního Managementu Euro-Krize. Acta Universitatis Carolinae - luridica 1/2012. Praha: Univerzita Karlova.

[9] Davidová, R. Systémy Zdravotního a Sociálního Pojištění U Nás a V Zahraničí (Diplomová Práce). Online. 2013 Cit. 2015-04-1. Dostupné Z: Http://is.Bivs.Cz/Th/20844/Bivs_M/Finalni_Verze.Pdf

[10] 0 Husenicová, L. 2013. Liberálne Hodnoty V Kontexte Globálnej Bezpečnosti. in Národná a Medzinárodná Bezpečnost' $2013: 4$. Medzinárodná Vedecká Konferencia. Liptovsky Mikuláš : Akadémia Ozbrojených Síl Generála Milana Rastislava Štefánika, 2013. Isbn 978-80-8040-475-8, S. 226-235.

[11] Mudrych, K., Mudrychová. J. Maturitní Otázky - Ekologie. Brno: Radek Veselý. 1. Vydání. 1999. 136 S. Isbn-10: 80902473-8-2.

[12] Host'ovecký, M., Zat'ková, T. Supporting the Development of Digital Competences of Pupils and Teachers. in: Iceta $2011:$ 9th leee International Conference on Emerging Elearning Technologies and Applications, October 27. - 28. 2011, Stará Lesná, the High Tatras, Slovakia: Proceedings / Cd Proceedings

Editor: Anikó Szakál. - . Vyd.. - Budapest, Hungary: Obbuda University, 2011. - Isbn 978-1-4577-0050-7. Pp. 75-78.

[13] Odbor Evropské Unie a Mezinárodní Spolupráce Mpsv. Sociální Zabezpečení Osob Migrujících V Rámci Evropské Unie. Praha: Ministerstvo Práce a Sociální Věcí, 2009. Str. 6. Isbn 978-80-7421-009-9.

[14] Bureš, J., Charvát, J., Just, P., Štefek, M. Česká Demokracie Po Roce 1989. Institucionálni Základy Českého Politického Systému. Grada, Praha, 2012, 526 Stran Isbn 978-80-247-4283-0

[15] Rubáček Filip. Prístupnost Webových Prezentaci Středních Škol V České Republice - Metody Testování a Základní Výsledky Provedeného Výzkumu. Media4u. 2011. Issn 1214-918. 